\title{
STUDENTS' ERROR IN PRONOUNCING MONOPHTHONG VOWELS
}

\author{
Wulan Wangi \\ FBS Universitas PGRI Banyuwangi \\ missmoon8182@gmail.com \\ Eka Citra Aprilliyanti \\ FBS Universitas PGRI Banyuwangi
}

\begin{abstract}
ABSTRAK
Berbicara merupakan salah satu keterampilan penting pada aspek berbicara yang harus diperhatikan dalam berkomunikasi. Dalam proses belajar bahasa Inggris, banyak pelajar merasa kesulitan mengucapkan bahasa Inggris terutama pada pengucapan vokal. Sementara, pengucapan yang salah dapat mempengaruhi makna dan akan menyebabkan kesalahpahaman. Tujuan dari penelitian ini adalah untuk menganalisis jenis kesalahan dalam pengucapan vokal monofthong (monophtong vowels) dan menganalisis kesalahan vokal yang paling sering terjadi pada bahasa Inggris. Penelitian ini menggunakan desain deskriptif kuantitatif dan metode cluster random sampling. Penelitian ini dilakukan di SMAN I GIRI dan responden adalah siswa kelas XI dengan jumlah responden sebanyak 68 siswa dari 2 kelas. Peneliti menggunakan tes lisan dan menggunakan rumus persentase untuk menganalisis data. Hasil penelitian menunjukkan bahwa jenis kesalahan yang sering dilakukan oleh siswa adalah penggantian dan penyisipan. Kemudian, kesalahan tertinggi yang paling salah diucapkan oleh mereka adalah dalam pengucapan / I / vokal dengan persentase total 97,06\%. Siswa disarankan untuk banyak berlatih pengucapan dan para guru disarankan untuk memberikan contoh yang benar dalam mengucapkan kata-kata bahasa Inggris terutama dalam vocal monofthong kemudian memberikan lebih banyak latihan dan latihan kepada siswa.
\end{abstract}

Kata Kunci: Pengucapan, Vokal Monoftong 


\section{INTRODUCTION}

English is very important in this globalization era. English is learned by all of students from Elementary school to University level. English has been introduced even in kindergarten students. It is used by people for business, college, politics and many others. It is very useful of mastering English by spoken or written in this globalization era considering that it gives many benefits for people. ${ }^{1}$ In Indonesia, English is taught as a foreign language. Thus, the students only get it at school and it makes them difficult to learn this language.

Teaching and learning English must concern on four language skills. Those are listening, speaking, reading and writing. Speaking is one of the important skills that should be mastered. It becomes parameter to measure communication. Speaking is known as a productive skill used as communication tool through oral form. Learners can express their thought, feeling, meaning, message, idea and also their opinion directly by speaking. Besides, speaking is quite difficult than any other skills because it requires the ability to perform in public. Indonesian learners still face some problems to communicate in English although they know speaking skill is very important. ${ }^{1}$ Therefore, speaking is needed in order to improve communication in English. It means someone cannot be said mastering a language if they cannot speak. This term makes speaking as the most important language skill to be learnt. ${ }^{2}$ So there is no excused not to learn English considering it is much needed nowadays. To enhance learners' speaking skill, they must consider several aspects in speaking. One of them is Pronunciation.

As one of speaking aspects, pronunciation must be known well by the learners. In learning foreign language, pronunciation takes a primary part on it. $^{2}$ Pronunciation directly affects learners' communicative competence as well as performance. It can decrease learners' confidence. Pronunciation is the act of producing the sounds of speech, including articulation, stress and

${ }^{1}$ Suryatiningsih,N., A Study on the Students' Ability in Pronouncing Diphthongs at STKIP PGRI Pasuruan. Jurnal Dimensi Pendidikan dan Pembelajaran, Vol 3 no.2 (Pasuruan: 2015)

2 Adawiyah, R., \& Retnowati, N. An Analysis on the Students' Errors in Pronouncing English Vowels (Bogor: Ibn Khaldun University, 2012) 
intonation. Firstly, learners should learn to hear the sounds accurately and listen to them closely and carefully. Pronunciation becomes priority in speaking so it cannot be underestimated. ${ }^{2}$ The more they hear the differences between the various sounds of English language, the better they will articulate them.

However, based on the writer's experience, the fact showed that there were many people who learn English often do not pay attention on their pronunciation and they generally guess when they will pronounce some words. As we know that there are several words which have the same sound but have different meaning. In this case, there will be many misunderstandings which were caused by mispronouncing words. For example someone pronounce some words, such as: fit and feet, sheep and ship, live and leave, bad and bed, at a glance there is no difference between them but it can lead misunderstanding when the learners do not know how to pronounce well because these words have very close pronunciation. The learners who have bad pronunciation, they cannot communicate efficiently although they are excellent in grammar and vocabulary. ${ }^{3}$

In the process of learning English, many learners are still confused to pronounce English sounds correctly, especially the English vowels. Therefore, the incorrect pronunciation can affect the meaning. Vowels are sounds in which there is no obstruction to the flow of air as it passes from the larynx to the lips. ${ }^{44}$ One of three kinds of vowels is Monophthong Vowels. It is a vowel sound that has single articulation position. On the other hand, there are two differences vowels between Bahasa Indonesia and English. The first is the number of vowel sounds. Bahasa Indonesia have six vowel sounds namely [i], [u], [o], [a], [e], and [ə] while English has twelve vowel sounds. It is divided into two kinds are Short vowels and Long vowels, which are $[\mathrm{I}],[\mathrm{e}],[\mathfrak{x}],[\Lambda],[\mathrm{p}],[\mathrm{\mho}],[\partial]$ known as a short vowels and [i:], [3:], [a:], [o:], [u:] for long vowels. ${ }^{4}$ For Indonesian, the vowel length will remain the same to pronounce in any words like seat and sit with first [sIt] and the second [sit]. They may regard the sounds similarly as just

\footnotetext{
${ }^{3}$ Riadi, A., Students' Problem in Pronouncing Short and Long English Vowels (Pontianak: Tanjungpura University, 2013).

${ }^{4}$ Roach, P., English Phonetics and Phonology (Cambridge: The Press Syndicate of the University of Cambridge, 2009).
} 
[sIt]. The second differences is English is known as an inconsistent language in pronunciation. For example word /good/this word should be pronounced as /god/. On the contrary, Bahasa Indonesia is a consistent language. The way words were spelling is the way to be pronounced. For example/tadi/it should be pronounced $/$ tadi $/{ }^{5}$

\section{METHOD}

Research design is detailed outline of how an investigation will take place. A research design will typically include how data will be collected, what instruments will be employed, how the instruments will be used and the intended means for analyzing data collected.

The researcher used descriptive quantitative research design because the researcher wanted to analyze students' kinds of error in pronouncing monophthong vowels at SMAN 1 GIRI Banyuwangi in the Academic Year 2018/2019.

The researcher would analyze kinds of students' error in pronouncing monophthong vowels. The researcher has choosen one of Senior High School in Banyuwangi. It is at SMAN 1 Giri. The area of this research is determined by using purposive method because this school is one of favorite school in Banyuwangi Regency. The researcher used population in Eleventh grade students because they have been taught speaking since in the tenth grade so it can be said they are in the intermediate level and got many vocabulary as well how to pronounce them.

Respondent determination method is commonly called sampling technique. ${ }^{6}$ Sample is a part of quantity and characteristic of population, while population is generalization area consist of object/subject that has quality and certain characteristic that is determined by the researcher to learn and generalize. ${ }^{77}$ Therefore in conducting the research, the researcher

${ }^{5}$ Mulansari, I., Basri, H., \& Hastini., The Analysis of the First Year Students' Errors in Pronouncing English Words. E-journal of English Language Teaching Society (ELTS), Vol 2 No. 3 (Palu: Tadulako University, 2014).

${ }^{6}$ Sukmadinata, N.S., Metode Penelitian Pendidikan (Bandung: PT. Remaja Rosdakarya, 2010).

${ }^{7}$ Sugiyono, Metode Penelitian Kuantitatif, Kualitatif dan R \& D (Bandung: Alfabeta, 2009). 
should get the appropriate data. The appropriate data can only be obtained from the reliable resource.

From the statements above the researcher uses cluster random sampling. The respondents are taken from the Eleventh Grade students at SMAN 1 GIRI. The total number of students is 224. The class XI was divided into eleven classes. They are from XI Science Program I to VII and XI Social Program I to IV. Each class consists of 30-32 students. The researcher will take 2 classes randomly from both programs. In conducting a research, it is necessary to collect the data in order to get the data provided in the research. Therefore, the researcher should take some methods mainly concern with how the data can be obtained well from the respondents.

\begin{tabular}{|c|c|c|c|c|}
\hline NO. & \multicolumn{2}{|c|}{ INDICATOR } & $\begin{array}{c}\text { NUMBER OF } \\
\text { ITEM }\end{array}$ & TOTAL \\
\hline \multirow{5}{*}{1.} & \multirow{5}{*}{$\begin{array}{c}\text { Pronouncing Long } \\
\text { Vowels }\end{array}$} & /i:/ & $1,3,25$ & 3 \\
\hline & & /a:/ & 2,14 & 2 \\
\hline & & $/ \mathrm{u}: /$ & 3,15 & 2 \\
\hline & & $/ 3: /$ & 4,16 & 2 \\
\hline & & $/ \mathrm{o}: /$ & 7,19 & 2 \\
\hline \multirow{7}{*}{2.} & \multirow{7}{*}{$\begin{array}{c}\text { Pronouncing Short } \\
\text { Vowels }\end{array}$} & $/ \mathrm{p} /$ & 5,17 & 2 \\
\hline & & $\mid \mathfrak{x} /$ & 6,18 & 2 \\
\hline & & $/ \mathrm{v} /$ & 8,20 & 2 \\
\hline & & $/ \mathrm{e} /$ & 9,21 & 2 \\
\hline & & $/ \Lambda /$ & 10,22 & 2 \\
\hline & & $/ \mathrm{O} /$ & 11,23 & 2 \\
\hline & & $/ \mathrm{I} /$ & 12,24 & 2 \\
\hline \multicolumn{4}{|c|}{ TOTAL } & 25 \\
\hline
\end{tabular}

Evaluation is getting data about status of something compared with standardized, because evaluate hold a measurement. The tool that used to collect the data is test. The test is list of question are assignment are tool which employed to measure skill, knowledge, intelligence, achievement and 
Wulan Wangi, Eka Citra Aprilliyanti

attitude of individual group. ${ }^{8}$

Based on opinion above, this research would use oral test for collecting the pronunciation score. Here, the researcher uses spoken test. There are 12 kinds of vowels including short and long vowel. The researcher gives 25 words to analyze what kinds of vowels' error and the most vowels' error pronounced by students are. The following is the distribution of the test item:

This study dealt with quantitative data, so the researcher works on the statistical analysis to analyze the data obtained. In analyzing the data, the researcher applied procedure as stated in the following:

a. The researcher gives the spoken instruments to the respondents which contain 25 words to be spoken.

b. Students produce the words and the researcher takes a record of the students' pronunciation.

c. The researcher collected the data from the recorder.

d. After collecting the data, the researcher counts the errors made by the students and made the percentage of each error.

e. Describing the results of the data to answer the research problems.

The collected data from test will be analyzed quantitatively by using percentage formula:

$P \frac{F q}{N} \times 100$

Notes:

$\mathrm{P} \quad=$ Percentage of students' error

$\mathrm{Fq}=$ Frequency of incorrect answers

$\mathrm{N}=$ Number of student (Sudjono in Basri and Mulansari, 2014)

To know the students' error, the researcher classified the difficulties based on standard which had proposed by Depdikbud in Mulansari and Basri as follows: 9

\footnotetext{
${ }^{8}$ Arikunto, S., Prosedur Penelitian Suatu Pendekatan Praktik (Jakarta: Rineka Cipta, 2006)

${ }^{9}$ Mulansari,The Analysis of the First Year Students' Errors in Pronouncing English
} 
a. $65 \%-100 \%$ is classified as high

b. $36 \%-64 \%$ is classified as moderate

c. $0 \%-35 \%$ is classified as low

\section{RESULT}

\section{Students' errors in pronouncing Monophthong Vowels.}

There were 12 kinds of Monophthong Vowels which were tested to the students. Based on the data analysis, it was found that students made three kinds of error. Kinds of error in pronouncing Monophthong Vowels were "substitution", "insertion" and "omission". There were 12 vowels which included in substitution. They were /i:/, /u:/, /3:/, /o/, /a:/, /x/, / :/, $/ \mho /, / e /, / \Lambda /$ In omission, there were 3 kinds of vowels, which were $/ \mathrm{a}: /, / \mathrm{p} /$ and $/ \partial /$ and there was only 1 vowel's error in omission, it was $/ \mho /$. These were the results of errors. Firstly was /i:/ vowel, the total of percentage were $33,33 \%$. Secondly was /a:/ vowel which got $76,48 \%$ errors. Thirdly was /u:/ vowel, total errors' percentage were $86,77 \%$. Next was $/ 3: /$ vowel which the total percentage of error were $54,41 \%$. The fifth was $/ \mathrm{D} /$ vowel with total percentage $79,41 \%$. The sixth vowel was $/ \mathfrak{x} /$ and the total percentage of errors were $61,77 \%$. Vowel $/ \mathrm{s} / /$ got $75 \%$ errors. For vowel $/ \mho /$ percentage of errors were $9,56 \%$. Total percentage errors for vowel /e/ were $82,36 \%$. Vowel $/ \Lambda$ had $69,86 \%$ errors. The other was $/ \partial /$ vowel with $52,94 \%$ errors and the last was /I/ vowels which had the highest errors $97,06 \%$ and it was classified as "high".

\section{Students' errors in pronouncing / $\mathbf{i}$ / / vowel}

In pronouncing this vowel, the students made "substitution" error on the three test items. Test item No.1 was "leave". Almost all of the students have the right answer. The correct pronunciation was /li:v/. In this item, 60 respondents have the correct answer $(88,24 \%)$ and they pronounced with long pronunciation. It meant only 8 students made an error $(11,76 \%)$ (see appendix 5, Table 1). Some of them pronounced as /lef/. The second was test item No.13 in word "reason". /ri:zn/ was the correct pronunciation. 12 students made error pronunciation (17,65\%) (see appendix 5, Table 2).

Words. E-journal of English Language Teaching Society(ELTS), Vol 2(3), 
They pronounced as /resn/ and /reasən/ but the others 56 got the right answer $(82,35 \%)$. The last item was No.25 "creature". Frequency of this error was 48. The correct pronunciation was / kri:t $\int ə(\mathrm{r}) /$. Most of them pronounced as $/ \operatorname{kret} \int \partial(\mathrm{r}) /$ and $/ \mathrm{kreatu}(\mathrm{r}) / .48$ students made an error with percentage $70,59 \%$. The total percentage of errors in this vowel were $33,33 \%$.

\section{Students' errors in pronouncing /a:/ vowel}

There were two test items in this vowel and students made two kinds of error which were "substitution" and "insertion". The first was "insertion" on the test item No.2 "guardian". The correct pronunciation was /ga:diən/ but they pronounced as how it was spelled /guardian/ and inserted / $\mathrm{u} /$ vowel, while the correct answer only got by 7 students with percentage $(10,29 \%)$. The total number of the students who made incorrect pronunciation in this word were $61(89,71 \%)$. The next was "substitution" on the test item No.14 "castle". The correct pronunciation was /ka:sl/. More than half students made an error. There were 43 students with percentage $(63,24 \%)$ were incorrect in pronouncing this word as /kestəl/ while few of them 25 students $(36,76 \%)$ could pronounce this word appropriately. The total percentage of errors in this vowel were $76,48 \%$.

\section{Students' errors in pronouncing /u:/ vowel}

This vowel contained two test items and two kinds of error which were "substitution and insertion". The first one was "insertion" on the test item No.3 "suitable". In this item, none of students could pronounce this word correctly. It meant the percentage of its error was $100 \%$. All of them pronounced as /suiteblə/. Whereas the appropriate pronunciation was /su:təbl/. Then, "substitution" for the test item No.15 "conclusion", frequency of this errors were 50 students $(73,53 \%)$ and the others 18 students pronounced correctly $(26,47 \%)$. The correct pronunciation was /kənklu:3n/ but the students pronounced as $/ \mathrm{k}$ : $:$ nklusion/. The total percentage of errors in this vowel were $86,77 \%$. 


\section{Students' errors in pronouncing /3:/ vowel}

In pronouncing this vowel, students made "substitution" error in two test items. "Purpose" was the first test item No.4, total percentage made by the students in pronouncing this word was almost 100\%. 55 students $(80,88 \%)$ pronounced as /porpose/ and /porpos/. It meant most of them made an error. The correct pronunciation was /p3:pas/ and 13 students $(19,12 \%)$ were correct. "Heard" No.16 was the second test item. The correct pronunciation was $/ \mathrm{h} 3: \mathrm{rd} /$, while 19 students pronounced incorrectly with percentage $(27,94 \%)$ as they pronounced /herd/ and /hird/ but most of them, 49 students $(72,06 \%)$ could pronounce it correctly. The total percentage of errors in this vowel were $54,41 \%$.

\section{Students' errors in pronouncing / $\mathbf{w} /$ vowel}

This vowel had two test items and two kinds of error. They were "substitution" and "insertion". The first was "substitution" error in "college", test item No.5. The students did not have good ability in pronouncing this word. From 68 students, none of them could pronounce properly. It meant that it had a high percentage (100\%). The appropriate pronunciation was $/ \mathrm{kplId} 3 /$. However, all of them tended to pronounce vowel as $/ \mathrm{o} / \mathrm{h}, \mathrm{ko}: \mathrm{leg} /$. The second was "insertion" in "honestly", test item No.17. The correct pronunciation was /pnistli/ and 28 students (41,18\%) were correct. In the other hand, more than $50 \%$ were wrong in pronouncing this word. 40 students $(58,82 \%)$ made an error as they pronounced /ho:nesly/. The total percentage of errors in this vowel were $79,41 \%$.

\section{Students' errors in pronouncing $/ \mathfrak{x} /$ vowel}

In this vowel, there were two test items. In pronouncing them, there was an error made by the students named "substitution". Firstly, test item No.6 "strategy". The students tended to pronounce this word in Indonesian way. Only 15 students $(23,53 \%)$ could pronounce properly as /strætdzi/ while the others 53 students $(76,47 \%)$ did errors pronunciation as they pronounced /str $\Lambda$ tegy/. Secondly was test item No.18 "actually", almost $50 \%$ of students pronounced incorrectly. Frequency of errors were 32 $(47,06 \%)$. They made error in pronouncing this word as $/ \Lambda \mathrm{ktuali} /$, when 
the other 36 students $(52,94 \%)$ could pronounce correctly as / akt $\int u ə l i /$. The total percentage of errors in this vowel were $61,77 \%$.

\section{Students' errors in pronouncing / $\mathbf{s}$ / vowel}

There were two test items in this vowel. Kind of error in this word was "substitusion" on two test items. Test item No.7 "caught" was the first. More than $80 \%$ the students got confuse to pronounce this word. Only 13 students $(19,12 \%)$ understood how to pronounce it as they pronounced /ks:t/. But 55 students (80,88\%) pronounced as $/ \mathrm{k} \Lambda \mathrm{f} / \mathrm{lnd} / \mathrm{k} \Lambda \mathrm{ug} /$. The second test item was No.19 "although". 21 from 68 students $(30,88 \%)$ could pronounce this vowel as /o:lðov/, while 47 students $(69,12 \%)$ did the error as they pronounced / $\Lambda$ ltof/. From these two words, they tended to pronounce as $/ \Lambda /$ vowel. The total percentage of errors in this vowel were $75 \%$.

\section{Students' errors in pronouncing / $/$ / vowel}

This vowel contained two test items and two kinds of error called "substitution" and "omission". The first was "substitution" on the test item No.8 "fulfill". This word made low percentage of error which only 6 students $(8,82 \%)$ pronounced incorrectly as /f 1 lfIl/. There were 62 students $(91,18 \%)$ understood well how to pronounce this word with short pronunciation as /fol'fIl/. "omission" error was made on the second test item was No.20 "pure". This word almost had the same errors frequency with one above, whereas 61 respondents $(89,71 \%)$ were correct in pronouncing as /pjoə(r)/ and the other 7 students (10,29\%) made error in pronouncing /por/. The total percentage of errors in this vowel were $9,56 \%$.

\section{Students' errors in pronouncing / $\mathrm{e} /$ vowel}

In pronouncing this vowel, the students made "substitution" error on two test items. Test item No.9 "pleasure" was the first item. There were 51 students $(75 \%)$ made errors in pronounced this word. The correct pronunciation was /plezər/. However, most of them were influenced by word "please" which pronounced as /pli:z/. So they tended to pronounce as /pli:sər/ and 17 students (25\%) could pronounce correctly. Test item No.21 
"spread" was the second item. Many students made an error in pronouncing this word. The correct pronunciation should be /spred/. There were only 7 students pronounced correctly $(10,29 \%)$. It meant 61 students made an error as they pronounced/spri:d/ and the percentage was $(89,71 \%)$. The total percentage of errors in this vowel were $82,36 \%$.

\section{Students' errors in pronouncing $/ \Lambda /$ vowel}

In this vowel, there was one kind of error on two test items named "substitution". Firstly was "muscle" in test item No.10. 27 of 68 students had the incorrect pronunciation $(39,71 \%)$. The correct pronunciation was /'m $\Lambda$ sl/ but they pronounced as /mosl/ or / moskle/. Frequency of students' correct answer were 41 (60,29\%). Secondly was "comfortable" in test item No.22. This word also included as the highest error because $100 \%$ from 68 students could not pronounce it. They pronounced as its first vowel /o:/, /ko:mforteblə/ whereas the correct pronunciation was $/ \mathrm{k} \Lambda \mathrm{mftabl} /$. The total percentage of errors in this vowel were $69,86 \%$.

\section{Students' errors in pronouncing / $/ \mathrm{p}$ vowel}

There were two test items in this vowel which made "substitution and insertion" error. No.11 "apartment" was the first item and consisted of those two kinds of error. Students pronounced this word with Indonesian way because it was similar with Bahasa Indonesia and inserted /ə/ vowel. 57 students with percentage $(83,82 \%)$ made error by pronouncing / $\Lambda$ partəmen/ while 11 students pronounced properly as /əpa:rtment/. No.23 "abroad" was the second item. Kind of error in this word was "substitusion". 15 students $(22,06 \%)$ did error as they pronounced / $\Lambda$ brod/ and the correct pronunciation /əbro:d/ achieved by 53 students with percentage $(77,94 \%)$. The total percentage of errors in this vowel were $52,94 \%$.

\section{Students' errors in pronouncing / $\mathbf{I}$ vowel}

This vowel contained two test items and the kind of error of them was "substitution". They were No.12 "effect" which only 4 respondents $(5,88 \%)$ could pronounce this word correctly. 64 respondents got the high percentage $(94,12 \%)$ in making errors. Most of them pronounced /efek/ as Indonesian way whereas the correct pronunciation was /Ifekt/. Next was test 
item No. 24 "delicious" and all of the students had difficulties in pronouncing this word. It was proven by data percentage that showed $100 \%$ errors. It meant all of them did not understand how to pronounce it. The correct pronunciation was /dilifes/, while the students pronounced as /dəlisias/ and /delisius/. The total percentage of errors in this vowel were $97,06 \%$.

\section{DISCUSSION}

Even though not all the students made an error but the students and the teachers must pay attention in pronouncing English Vowels especially for monophthong Vowels. From the results above showed that the highest five percentage, students still made a high error in pronouncing $/ \mathrm{I} /, / \alpha: /$, /u:/, /e/ and /p/.

Here are kinds of vowel error made by the students. The first was substitution. It took over most in pronunciation error. Likely, vowel /ə/ became /e/ in word "suitable" /su:təbl/, became $/ \Lambda /$ in word "abroad" /əbro:d/ and "apartment" /əpa:rtment/ and became / $/ \mathrm{s}$ in word "conclusion" /kənklu:3n/. Vowel/3:/ became / / in word "purpose" /p3:pəs/ and became /I/ in word "heard" /h3:rd/. Vowel /I/ became /e/ in word "effect" /Ifekt/ and "delicious" /dIIISes/, vowel /e/ became /I/ in word "spread" /spred/ and pleasure" /plezər/, vowel $/ \Lambda /$ became $/ \mho /$ in word "muscle" $/ \mathrm{m} \Lambda \mathrm{skl} /$ and became $/ \mathrm{o}: /$ in word "comfortable" $/ \mathrm{k} \Lambda \mathrm{mft} ə \mathrm{bl} /$, vowel $/ \mathrm{s}: /$ became $/ \Lambda$ in word "although" $/ \mathrm{s}: 1 ð$ ov/ and "caught" $/ \mathrm{ks}: \mathrm{t} /$, vowel /i:/ became /e/ in word "leave" /li:v/, "reason"/ri:zn/ and "creature" /kri:t $\int ə(\mathrm{r}) /$, vowel /a:/ became /e/ in word "castle" /ka:sl/, vowel/p/ became $/ \mathrm{s} /$ in word "college" $/ \mathrm{kplId} 3 /$, vowel $/ \mathfrak{x} /$ became $/ \Lambda /$ in word "strategy" /strætdzi/ and actually /ækt $\int u ə l i /$ and vowel $/ \mho /$ became $/ \Lambda /$ in word "fulfill" /ful'fll/. The other kind of error made by the students was insertion. For example the insertion of vowel /o/ in word "apartment" /opa:rtment/. It pronounced by the students as /apa:rtəment/, vowel / $\mathrm{u} /$ in word "guardian" /ga:dian/ students pronounced as /guardian/, sound /h/ in word "honestly" P'pnistli/ while students pronounced as /ho:nesly/, and the last insertion was vowel /I/ in word "suitable" /su:təbl/ as they pronounced/suiteblə/. The next kind of error was "omission" which sound / $\mathrm{j} /$ disappeared in word 
"pure" /pjoə(r)/ as students pronounced as /por/.

There are some factors that influenced students' pronunciation. They are inconsistency of English vowels, mother tongue and teacher's role. Firstly was inconsistency of English vowels in pronunciation. For example in pronouncing words "purpose" and "creature". They pronounced /porpos/ and /kreatur/ as how it was spelled in Bahasa. In word "purpose" the first vowel was $/ \mathrm{v} /$ but it must be pronounced as $/ 3: /$. This happened because Bahasa Indonesia was a consistent language which could be pronounced as its spelled, while English was an incosistent language. There was no relation between the sound uttered and the letter which appeared in word.

Then, the other factor was mother tongue, for example in words "apartment", "effect" and "strategy". These were similar with Indonesian word and they tended to pronounce / $\Lambda$ partəmen/, /efek/ and /str $\Lambda$ tegy/ rather than /əpa:rtment/, /Ifekt/, /strætdzi/ as the correct pronunciation. The students faced some difficulties because in Indonesia the vowel system was simple but in English the vowel system was confusing. They may pronounce $/ \mathrm{e} /$ as $/ \mathrm{I} /, / \alpha: /$ as $/ \mathfrak{x} /$, etc.

The last factor was teacher's role. The students never got pronunciation training from the teachers. This argument was supported by the students' statement. They said that they only had enough ability in pronunciation. Besides, they were rarely looked up dictionary to check the correct pronunciation.

\section{CONCLUSION}

This research is aimed to analyze kinds of vowel error and the most mispronounced vowel made by the students. The kinds of error in pronouncing Monophthong Vowels made by were Substitution and Insertion. The most frequently mispronounced vowel was /I/ vowel.

\section{SUGGESTION}

From the conclusion above, the researcher would like to give some suggestions. The teachers must give correct example in pronouncing English words especially in Monophthong Vowels. They might give more 
drills and practices in order to avoid misunderstanding between the speaker and listener. The students are suggested to practice a lot in pronunciation in order to improve their communication skill by looking up the online dictionary which provide the model of how to pronounce the words and asked teacher the unknown material. For the future researchers, they could use this result as a reference to conduct further research to overcome students' pronunciation problems by using an appropriate technique.

\section{REFERENCES}

Adawiyah, R., \& Retnowati, N. (2012). An Analysis on the Students' Errors in Pronouncing English Vowels. Bogor: Ibn Khaldun University

Arikunto, S. (2006). Prosedur Penelitian Suatu Pendekatan Praktik. Jakarta: Rineka Cipta

Mulansari, I., Basri, H., \& Hastini (2014). The Analysis of the First Year Students' Errors in Pronouncing English Words. E-jowrnal of English Language Teaching Society(ELTS), Vol 2(3), 1

Riadi, A. (2013). Students' Problem in Pronouncing Short and Long English Vowels. Pontianak: Tanjungpura University

Roach, P. (2009). English Phonetics and Phonology. Cambridge: The Press Syndicate of the University of Cambridge

Sukmadinata, N.S. (2010). Metode Penelitian Pendidikan. Bandung: PT. Remaja Rosdakarya

Sugiyono. (2009). Metode Penelitian Kuantitatif, Kualitatif dan R \& D. Bandung: Alfabeta

Suryatiningsih,N. (2015). A Study on the Students' Ability in Pronouncing Diphthongs at STKIP PGRI Pasuruan. Jurnal Dimensi Pendidikan dan Pembelajaran, Vol 3(2), 1-4 